\title{
Tomasz Koper
}

Badacz niezależny (independent researcher)

ORCID 0000-0001-5569-9670

DOI https://doi.org/10.21697/ucs.2021.27.1.04

\section{CYGANIE (ROMOWIE) A ICH HISTORIA. MITOLOGIA „WIECZNEJ” WĘDRÓWKI (ZARYS PROBLEMU)}

\author{
The Gypsies (Roma People) and their history. The mythology of „eternal” travelling \\ (the outline of the issue)
}

\begin{abstract}
Streszczenie
Artykuł omawia w kontekstach historycznych zagadnienia związane z nomadyzmem Cyganów. Punktem wyjścia jest założenie o istnieniu mitologicznego sposobu myślenia o ich wędrówkach (nomadyzmie, półnomadyzmie). Utrwalił się on zarówno w myśleniu większościowym, jak i w percepcji samych Cyganów. Przykładami opisanymi w artykule są postawy określonych państw i polityka realizowana wobec Romów. Autor przedstawił również sposoby poruszania się Cyganów po drogach Europy.
\end{abstract}

Słowa kluczowe: koczowniczy (półkoczowniczy), Cyganie, historia, represje, mitologia

\begin{abstract}
The article discusses issues related to the nomadism of Gypsies in historical contexts. The starting point is the assumption that there is a mythological way of thinking about their journeys (nomadism, semi-nomadism). It persisted both in the majority thinking and in the perception of the Gypsies themselves. The examples in the article are the attitudes of certain countries and the policy pursued towards them. The journeying of the Gypsies on the roads of Europe is also presented.
\end{abstract}

Key words: nomadic (semi-nomadic), Gypsies, history, repressions, mythology

\section{Wstęp}

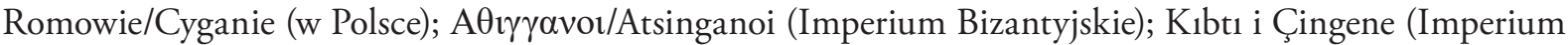
Otomańskie, Turcja); Цигани/Tsigani (Serbia, była Jugosławia); Zigeuner (Niemcy, Austria); Mustalased (Estonia); Cigányok (Węgry) itd. (zob. Marushiakova, Popov 2018: 387) to najliczniejsza (transgraniczna) mniejszość etniczna/narodowa w Europie. Populację tę szacuje się na 9-12 mln osób, z czego dwie trzecie mieszka w Europie Środkowej i Wschodniej (FRA 2016: 2). Według danych Narodowego Spisu Powszechnego Ludności i Mieszkań z 2011 roku w Polsce 16723 osób zadeklarowało przynależność do romskiej mniejszości etnicznej (GUS 2011). Władze administracji terytorialnej oraz krajowe organizacje romskie uważają, że dane z 2011 roku są szacunkami zaniżonymi, a ogólna, nieoficjalna liczba populacji romskiej może wynosić od 20 000 (MSWiA 2004-2013) do ok. 35000 osób. Obie nazwy Romowie/Cyganie będę w niniejszym artykule stosował zamiennie, mając na uwadze liczne ograniczenia, które mogłyby się pojawić podczas prezentowania rozważań teoretycznych.

Klasyfikacja sub/meta grup romskich jest właściwie niemożliwa. Można jedynie zgodzić się, że: „Istniejąca terminologia etnologiczna zdaje się być niezbyt dopasowana do możliwości nazwania poszczególnych poziomów zróżnicowania i organizacji społecznej Cyganów” (Mirga i Mróz 1994: 102). Dla przyzwoitości należy 
jednak dodać, że część ludności cygańskiej żyjącej na terenie Europy nie identyfikuje się z nazwą Romowie (Roma jako „umbrella term”). Określenie Cyganie (ang. Gypsies) - szersze znaczeniowo - w sposób bardziej trafny oddaje naturę ich lokalnych wspólnot społeczno-kulturowych. Postawę taką wyrażają następujące społeczności: Manusze (Francja, Włochy, Niemcy, Ameryka Północna); Sinti (Austria, Szwajcaria, Włochy, Niemcy, rejony przygraniczne Francji; Gitanos (Hiszpania, Portugalia, południowa i zachodnia Francja; oraz Romanichels, znani również jako Travellers (Wyspy Brytyjskie, Ameryka Północna). Autor odsyła zatem czytelnika do obszernego zbioru literatury, która próbuje ten stan usystematyzować i tym samym nieco ułatwić orientację w tej problematyce (Liégeois 2007). W Polsce korzenie nomadyczne mają następujące grupy: Polska Roma (określani również jako Cyganie nizinni), Kełderasze i Lowarzy. Z dawna osiadłą (od stuleci) jest grupa Bergitka Roma, czyli Cyganie karpaccy (Ficowski 1965).

Celem artykułu jest próba dokonania syntetycznych opisów historycznych, które posłużą za przykłady (źródła) myślenia mitologicznego na temat Cyganów. Są one częścią ogólnej (globalnej) percepcji większościowej. Przedstawione zostaną niektóre aspekty historyczne związane z węd rówką (nomadyzm, półnomadyzm) tej ludności. Autor omawia również przykłady politycznych rozwiązań (ustawy i rozporządzenia) skierowane przeciwko ludności cygańskiej, a także sposoby jej poruszania się po drogach Europy. Dodatkowym założeniem jest przyjęcie perspektywy większościowej, która współtowarzyszy opisom i tematom historiograficznym, z powodu braku alternatywnej perspektywy wobec danej rzeczywistości. Zdaniem L. Mroza „koczowanie stało się nie wyborem, ale koniecznością ochrony egzystencji, a czasami wręcz życia. Od tego momentu cygańskie migracje mają wyraźnie charakter ucieczkowy - to właśnie w znacznym stopniu określa formowanie się i późniejszy kształt cygańskiej kultury” (Mróz 2010, 2001: 140; Mayall 1988; Frazer 1992).

\section{Metodologia}

Do opisu zarysowanych we wstępie zagadnień została wybrana procedura naukowa wykorzystująca myślenie syntetyczne, której założenie jest następujące: „porównywanie, abstrahowanie i uogólnianie zmierza do wykrywania w połączonej, nowej całości istotnych właściwości i zależności (związków)" (Apanowicz 2002: 25). Mitologia będzie tu rozumiana szeroko: „Mityczne historie są lub wydają się arbitralne, pozbawione znaczenia, absurdalne, a mimo to wydają się pojawiać na całym świecie [...] mit jest nieskuteczny w zapewnianiu człowiekowi większej władzy materialnej nad środowiskiem. Jednak, co bardzo ważne, daje człowiekowi iluzję, że może zrozumieć wszechświat [...] To oczywiście tylko złudzenie" (Lévi-Strauss 1978: 3 i 8).

Termin: „nomada” wywodzi się od greckiego słowa nemein, które oznacza „paść, wypasać bydło” (Liégeois 1995). Takie też pierwotne znaczenie przypisuje się nomadyzmowi. Antropologia potwierdza, że hodowla bydła była w VII i VII w. p.n.e. rzekomym przyczynkiem zmiany stylu życia na nomadyczny. Przykładem niech będzie Azja, w której nomadów (pastoral nomads) było ok. 1,5 mln osób (Kradin 2002: 373).

W literaturze przedmiotu można odnaleźć różnorodne określenia sposobów funkcjonowania ludności cygańskiej z uwagi na wykonywane przez nią usługi dla społeczeństwa dominującego, np. nomadyzm usługowy (service nomads), który polega głównie na wymianie dóbr i usług z okoliczną (osiadłą) społecznością.

Niektóre grupy wyspecjalizowały się w specyficznym sposobie zarabiania, jak pisze Hayden, podając liczne przykłady z Indii (Hayden 1979). W literaturze używane są również pozostałe określenia: nomadyzm ekonomiczny (economic nomads) (Acton 1974), a także nomadyzm rzemieślniczy (craftsman nomads) (Hubschmannova 1974: 58). Wyróżnia się jeszcze inne rodzaje nomadyzmu, np. nomadyzm niezwiązany z produkcją żywności (non-food producing nomads) (William 1982: 115) czy też ruchome populacje przemysłowe (floating industrial populations) (Nemeth 1970: 43). Istnieją też dwa dodatkowe określenia: wędrowne szczepy (peripatetic tribes) (Varady 1982: 54) oraz nomadyzm handlowy (commercial nomads) (Acton 1981: 2).

Słowo „tabor” funkcjonuje wyłącznie w literaturze. Nie ma również odpowiednika w języku romskim (romani ćhib, romanes). Warto dodać, że słowo to „Cyganie przejęli od gadziów, a raczej gadziowie im ten termin wmówili. Młodzi przyjmują go dziś jako oczywisty, rodzimy, nie kojarząc, że to słowo dotarło m.in. z mediów (Jadą wozy kolorowe taborami)” (Bartosz 2009: 278; Kapralski 2018: 11).

W grupach wędrownych za synonim taboru może uchodzić słowo „kumpania”. Był to „czasowy związek rozrodzonych rodzin, niekoniecznie i nie zawsze spokrewnionych ze sobą”" (Mirga, Mróz 1994: 123). Niektóre 
kumpanie są sezonowe, inne zaś działają przez dłuższy czas w celach ekonomicznych. Jest to zazwyczaj sieć osób pochodzących z jednej grupy romskiej, która jest związana z danym tery torium (nacja) (Kamiński 1980: 40-41).

\section{Centrum i peryferia (marginesy) społeczne}

Mobilność przestrzenna była w średniowiecznej Europie zjawiskiem powszechnym. Po ówczesnych gościńcach i traktach, w ramach nauki zawodu (fr. apprentissage) wędrowali: rycerze, czeladnicy, rzemieślnicy, scholarze, zakonnicy, jak również ludzie przynależący do marginesu społecznego: wykluczeni, złoczyńcy, kontestatorzy, heretycy i dewianci, określani zbiorczą nazwą jako „ludzie gościńca” (Baranowski 1986). Cyganie nie byli zatem jedyną grupą ludzką, która wędrowała w średniowiecznych czasach.

Nieakceptowani byli również tacy odmieńcy jak: dzicy, monstra, poganie i innowiercy z uwagi na powszechną ideę i wizję chrześcijańską (Geremek 1984: 706 i 710; Mróz 1995: 341). Ponadto wędrowali także weterynarze (tzw. konowałowie), kastratorzy (tzw. misiarze). Ci pierwsi, oprócz umiejętności leczniczych, powinni posiadać również wiedzę z zakresu magii: „taki konował musiał znać cały szereg odpowiednich "zamówień", za pomocą których przepędzał złe siły, znajdujące się wewnątrz zwierzęcia. [...] Konowałami i misiarzami bardzo często byli Cyganie [...]” (Baranowski 1986: 97).

Akty mobilności przestrzennej, jak pisze wspomniany już Bronisław Geremek, nie były równoznaczne z życiem aspołecznym. Dla średniowiecznej ludności tereny zasiedlone były zjawiskiem pozytywnie wartościowanym. Dawały np.: poczucie bezpieczeństwa, stabilność, zakorzenienie, poczucie porządku społecznego, które wyrażało się w pozytywnych więzach społecznych i sąsiedzkich. Z kolei tereny niezagospodarowane (pustkowia) i dzikie tereny leśne budziły strach i były jednoznacznie uważane za niebezpieczne. Zjawisko pozostawania na peryferiach społecznych, lokowania się „poza centrum”, czyli w geograficznej „obcości”, ma również wymiar socjokulturowego i ideologicznego naznaczenia. Włóczęgostwo, na równi ze złodziejstwem, było uznawane za sprzeczne z ogólnie przyjętymi normami społecznymi, stanowiło tym samym ewidentny przejaw społecznej marginalizacji. Bronisław Geremek pisze: „,...] w samej podróży tkwi pewien element marginalizacji, albo przynajmniej niebezpieczeństwo marginalizacji. Oto człowiek opuszcza swe naturalne środowisko: wystawia się na niebezpieczeństwa drogi, stosunki z nieznanymi ludźmi, niespodzianki przyrody. [...] Te groźby towarzyszyły [...] każdej podróży, z którą związane było opuszczenie przestrzeni swojej [...] ustabilizowanej i bezpiecznej" (Geremek 1989: 706-707).

Poczucie niechęci i wrogości wobec Cyganów ma odległe przyczyny historyczne. Proces modernizacji społeczeństw europejskich zaczął się, gdy Cyganie mieli swoje miejsce w społecznościach europejskich jako „ludzie gościńca”. Na ogół byli traktowani podobnie jak inne grupy, stanowili bowiem jeden z elementów mozaiki etnicznej w wielokulturowej Rzeczypospolitej Obojga Narodów. Według danych obszar II Rzeczpospolitej zamieszkiwało aż 35,1\% mniejszości narodowych (Chałupczak i Browarek: 28); w tym również mniejszość cygańska (romska). Z czasem ich wizerunek zaczął sukcesywnie ulegać zmianie. Cyganie i ich nomadyczny sposób życia stanowili zagrożenie dla modernizującej się Europy, której podstawową cechą była standaryzacja (proces ujednolicenia) grup ludzkich. Stali się zatem antytezą nieromskich przemian cywilizacyjnych i społecznych (postmodernistycznych) (Kapralski 2012), a także tworzyli w późniejszym czasie grupę „kontrkulturową” (tzn. aspołeczną). Andrzej Mirga dodaje: „Grupa tego typu, w przekonaniu większości, jawnie odrzuca i przekracza normy społeczeństwa, traktowana jest więc jako dewiacyjna i zazwyczaj staje się obiektem uprzedzeń i dyskryminacji” (Mirga 1997: 156). Dodatkowo na tej samej stronie w przypisie wspomniany autor pisze, że grupy cygańskie były później traktowane przez faszystów: „[...] jako problem ludzi nie nadających się do zużytkowania i obciążonych dziedzicznie przestępczością", co stało się znaczącym przyczynkiem późniejszej „ideologii eksterminacyjnej wobec tej ludności” (Mirga 1997: 156). Początkowo konflikt ten był oparty na odmiennych systemach wartości, później przerodził się w walkę ideologiczno-rasową.

\section{Cyganie jako „pierwsi Europejczycy”}

W połowie XI w. zostało odnotowane pojawienie się Cyganów w prowincji Anatolia (Antalya), która pod panowaniem rzymskim określana była jako Azja. Niektóre z zachowanych źródeł mówią również o pobycie 
Cyganów w Wenecji, a także na wyspie Korfu, należącej do dynastii Andegawenów, na przełomie XIII i XIV w. Grupowy exodus Cyganów z terenów Grecji i Bałkanów był prawdopodobnie spowodowany ekspansją Turków Osmańskich, którzy w tamtym czasie wkroczyli na tereny bizantyjskie w celu szerzenia przymusowej islamizacji wśród podbitej ludności (Frazer 2001: 47).

Wzmianki historyczne pochodzące z XIII-XV w. dotyczą natomiast Półwyspu Bałkańskiego, krajów azjatyckich i południowej Europy. Lech Mróz sugeruje, że to właśnie wtedy Cyganie podróżowali na pieszo. Dzieci i dobytek były przewożone na wozach (ciągniętych przez osły lub muły), a dorośli szli obok (Mróz 1979: 85). W Europie granice krajów wciąż ulegały zmianom. Być może jest to główny powód, dla którego wspomniany autor pisze o wojsku jako elemencie mającym wpływ na bytowanie grup cygańskich. Dodaje również, że namioty nie były wtedy znane, a szałasy w obozowiskach budowano z kamieni i liści. Pierwsza wzmianka historyczna na temat użycia koni do ciągnięcia wozów pochodzi z Serbii (1348 r.). Mróz jednak zaznacza, że pojawienie się wozów konnych u Cyganów jest wzmiankowane w różnych źródłach historycznych, pochodzących z wielu krajów centralnej i zachodniej Europy, już od XV w. Pisano o nich w Niemczech (1417), w Bazylei (1422) i w Paryżu (1423). W tamtym czasie Cyganów nie uznawano za włóczęgów, byli ,jednym z elementów mozaiki narodowościowej, a nie wzorcowymi obcymi” (Mróz 2001: 91; 2010).

W średniowiecznej Europie powstały liczne ustawy i edykty dotyczące banicji (ekspulsji) Cyganów lub ich przymusowej asymilacji w różnych krajach. W $1471 \mathrm{r}$. ustanowiono pierwsze prawo antycygańskie w Lucernie (Szwajcaria). Podobne ustawy i rozporządzenia pojawiły się w Brandenburgii (1482 r.) i w Hiszpanii (1492 r.). Maksymilian I wydał zbiór rozporządzeń (np.: z 1496 r., 1497 r., 1498 r., 1500 r. i pozostałe lata), które zmuszały Cyganów do opuszczenia terytorium ówczesnych Niemiec.

Cyganie stykając się z obcym środowiskiem, niecygańskim, przyswajali wiedzę na temat warunków życia okolicznych społeczeństw i elementów kultury ich przedstawicieli. Co ważniejsze, poznawali także: „sposób myślenia i cechy mentalne Europejczyków” (Mróz 1995: 342). Akta grodzkie i ziemskie wymieniają osoby określone jako „Cygan” (oryg. „Czigan”). Piastowały one często najwyższe stanowiska folwarczne i służby domowej w Rzeczypospolitej i Wielkim Księstwie Litewskim. Stan ten zmienił się bezpowrotnie w następnym stuleciu - w połowie XVI w., za sprawą cygańskich grup koczowniczych, które tworzyli uciekinierzy z krajów Świętego Cesarstwa Rzymskiego 962-1806 r., a dokładniej z Niemiec, państw zachodnich oraz z południa: Siedmiogrodu, Mołdawii i Węgier (Mróz 2001: 88; 2010: 164-165).

Wpływ, jaki wywarła cywilizacja europejska na ludność cygańską w kontekście ich wielowiekowego pobytu na kontynencie, daje podstawę niektórym autorom do określania ich mianem Europejczyków. Zdaniem Ewy Nowickiej europejskość Romów może być rozumiana w trzech wymiarach. Pierwszy wymiar to posługiwanie się językiem wywodzącym się z grupy języków indoeuropejskich podobnie jak większość narodów europejskich. Drugi wymiar to swoboda przemieszczania się, a trzeci to posiadanie szerokiej sieci europejskich kontaktów (Nowicka 2005: 39).

\section{Dwie kategorie Cyganów w Rzeczypospolitej Obojga Narodów (1569-1795)}

Najstarsza wzmianka historyczna odnotowująca nazwę mającą związek z Cyganami pochodzi z 9 listopada 1401 r. Została ona zawarta w księgach radzieckich (rady miejskiej) Kazimierza i dotyczy niejakiego Mikołaja Cygana (org. Micolay Czigan). Prawdopodobnie pochodził z Czech lub z Węgier i dokonał wpłaty podatku wynoszącego połowę grzywny za dzierżawę ziemi w Zapłociu (Acta consul. Casimir., ks. IV, s. 548, AP Kraków, Oddz. III, sygn. K 4, za: Mróz 2001:19 i n.). Wzmianka ta wydaje się przeczyć wizerunkowi Cygana jako obcego znanemu z czasów współczesnych. Przeczy także wizerunkowi beztroskiego wagabundy, pielgrzyma i cyrkowca czy też mistycznego wróżbity. Przykładem niech będzie Piotr Czigan, właściciel ogrodu przy Bramie Halickiej i sporej posiadłości umiejscowionej na rynku we Lwowie. Z księgi miejskiej przychodów i rozchodów za lata 1405-1414 wynika, że Piotr Czigan był osobą majętną i płacił podatki kilkukrotnie: w 1405, 1406, 1408, 1410 r. (Percepta et expisita civitatis, 1404-1414, s. 55 i n., CDIA Lwiw, sygn. F.52, o.2, nr 695, za: Mróz 2010: 163). Z kolei Jan Czigan posiadał prawa miejskie miasta Krakowa w 1411 r. Osoby te często miały wysoką pozycję społeczną, posiadały prawa miejskie i szlacheckie. Zdarzały się również przypadki pełnienia służby u króla (np. w charakterze łożnego lub łożniczego (łac. cubicularius), czyli pracy polegającej 
na ścieleniu królewskiego łoża. Istnieje również opisany przypadek Cygana - szlachcica, który w ramach pospolitego ruszenia uczestniczył w działaniach wojennych. Informacje te wskazują na wysoki stopnień asymilacji z niecygańskim otoczeniem i na brak konfliktów społecznych. Jak pisze Mróz: „Wszystkie znane XV-wieczne wzmianki źródłowe z terenów Polski są jedynie poświadczeniami pojawienia się lub bytności Cyganów - a ściślej pojedynczych osób, określających siebie mianem Cyganów. Nie jest znany ani jeden dokument z owego czasu, który mówiłby o Cyganach jako grupie etnicznej” (Mróz 2001: 42).

Pierwsze wzmianki o uciekinierach z krajów Cesarstwa Rzymskiego, a więc o Cyganach w rozumieniu etnicznym, pochodzą z XVI-wiecznych źródeł historycznych. Te same źródła charakteryzują Cyganów jako Egipcjan lub jako Filistynów z Małego Egiptu. (Nazw tych używano w Bizancjum już w XIII w.). W dokumentach z przełomu XV i XVI w. można odnaleźć wzmianki o osobach pochodzenia cygańskiego wymienianych z imienia i nazwiska, np.: Jan Zeleniski - akta krakowskie 1554 r., Łukasz Wojciechowicz akta mielnickie 1576 r. (Mróz 2001: 82).

Wrogi stosunek Europejczyków do Cyganów (u schyłku średniowiecza i na początku renesansu) od połowy XVI w. zaczyna się umacniać. Zaczęły się również kradzieże i rozboje popełniane przez nomadyczne cygańskie grupy. Dokumenty i wzmianki historyczne z tego okresu wskazują na negatywne nastroje społeczne zogniskowane wokół Cyganów. Zaczęto dostrzegać zagrożenie z ich strony na terenie niemal całej Europy. $\mathrm{Na}$ ziemiach Rzeczypospolitej Cygan staje się synonimem koczownika, na terytorium Wielkiego Księstwa Litewskiego nazwa ta odnosi się zarówno do osiadłej, jak i koczującej ludności (Mróz 2001; 2010). Mimo że polityki państw europejskich przeciwko tej grupie mniejszościowej były realizowane w różny sposób, to ich wspólny element jest w istocie: „historią odbitą w świadomości nie-Cyganów, w której sami Cyganie rzadko mówią własnym głosem. Jest pisana przez nie-Cyganów i rekonstruowana ze śladów pozostawionych przez nie-Cyganów [...] Dlatego też Cyganie są bardziej przedmiotem [...] niż podmiotem tej historii” (Mirga, Mróz 1994: 31).

Pośród 34 dokumentów źródłowych pojawia się również szereg wzmianek dotyczących grup koczowniczych (dokładnie sześć zapisów historycznych). Opisują one cygańskie grupy, które przywędrowały zza zachodniej oraz południowej granicy Rzeczypospolitej. Najprawdopodobniej z terenów Mołdawii, Siedmiogrodu i Węgier. Z zapisków wiadomo, że nie wszystkie grupy prowadziły koczowniczy tryb życia. Niektóre ograniczały swój nomadyzm jedynie do danego obszaru, prowadząc półosiadły, a nawet osiadły tryb życia, wskazuje na to np. akt miński z 1595 r. Pięć dokumentów źródłowych to opisy dokonanych przestępstw, z czego trzy wzmianki dotyczą przestępstw popełnionych przez grupy, pozostałe dwie - przez jednostki. Pierwszy grupowy protokół z przesłuchania osób oskarżonych o akt złodziejstwa pochodzi z 1554 r. Interesujący jest również akt z 1576 r., który opisuje skargę sądową złożoną przez Łukasza Wojciechowicza, urzędnika wojewody podlaskiego (Mikołaja Kliszki), na Pawła Cygana.

W XVI w. na terytorium Królestwa Rzeczypospolitej i Wielkiego Księstwa Litewskiego istniały dwie kategorie, które umownie można nazwać Cyganami. Jak pisze Mróz, pierwsza z nich to „Filistyni” lub „przybysze z Małego Egiptu”. Była to grupa osiadła, żyjąca w Wielkim Księstwie Litewskim. Otoczenie większościowe nie dostrzegało w nich zagrożenia. Druga populacja jest raczej nomadyczna (pochodząca z terenów Rzeczypospolitej), co podkreślało jej obcość. Cechy antropologiczne (rasowe) nie przyczyniały się do postrzegania Cyganów jako obcych. Powodem był nomadyzm - tryb życia, który z perspektywy większości uznawany był za aspołeczny i kojarzył się z marginesem społecznym na terenie wielu krajów Europy wschodniej i centralnej (Mróz 2001: 87), w tym również w średniowiecznej Francji (Geremek 1984).

\section{Doktryna faszystowska}

Doktryna faszystowska, czerpiąc w sposób selektywny z przyrodniczej koncepcji o dziedziczeniu w ujęciu Karola Darwina, stworzyła koncepcyjne podstawy walki rasowej. W 1926 r. powstała ustawa: Prawo o zwalczaniu Cyganów, wędrowców i osób uchylających się od pracy. Na mocy tej ustawy tworzono miejskie obozy cygańskie, pośród których największym był Rastplatz Marzahn, położony $10 \mathrm{~km}$ od Berlina. Od 1936 do 1945 r. około 1200 rodzin (Romów i Sinti) zostało zmuszonych do przebywania w obozie. Powstał on w przededniu letnich igrzysk olimpijskich w Berlinie, po tym jak minister spraw wewnętrznych Rzeszy 
Wilhelm Frick wydał dekret o „zwalczaniu plagi cygańskiej” na początku czerwca 1936 r. Wspomniany obóz był nadzorowany głównie przez policję kryminalną (Kripo) w Berlinie. W 1936 r. około 600 osób mieszkało w 130 wozach i w jednym baraku mieszkalnym.

Powszechnie uznaje się, że liczba ofiar w wyniku działań reżimu hitlerowskiego wyniosła ok. 500 tys. osób (Fonseca 1995: 243; Steward 2007: 5-8). Wśród pozostałych badaczy opinie na ten temat są jednak podzielone. Zdaniem Donalda Kendricka i Grattana Puxona liczba ofiar wyniosła ok. 219 tys. osób (Kendrick i Puxon 1972: 183-184). Z kolei Ian Hancock jest zdania, że rzeczywista liczba ofiar jest znacznie wyższa i oscyluje wynosi ok. 1-1, 5 mln osób (Hancock 2002: 48).

W 1938 r. powstał dekret Heinricha Himmlera o „zwalczaniu plagi cygańskiej”. Przyczyną tzw. opóźnienia był brak eksperta do spraw cygańskich. Został nim psychiatra dr Robert Ritter. Badania, które przeprowadził na populacji Cyganów zamieszkujących ówczesne tereny Niemiec, miały na celu znalezienie zależności pomiędzy genetyczną dziedzicznością a skłonnościami do przestępstw. Oznaczenia rasowo-biologicznej oceny, jakie w nich zastosowano, to: Z (czysty Cygan), ZM+ (Cygan mieszany z dominującą domieszką krwi cygańskiej), ZM (Cygan mieszany; równy podział domieszek); ZM - (Cygan mieszany z dominującą domieszką krwi niecygańskiej); NZ (nie-Cygan) (Frazer 2001: 191). Badaniami nad Cyganami zajęły się dwie instytucje: Instytut Badania Higieny Rasy, ustanowiony przy ministerstwie zdrowia Rzeszy, oraz Instytut KryminologicznoBiologiczny przy Urzędzie do Spraw Bezpieczeństwa Rzeszy.

W 1940 r. zostało rozesłane pismo sygnowane przez Himmlera, polecające organizację pierwszych transportów cygańskich do obozów koncentracyjnych i gett żydowskich znajdujących się w Polsce. List ten ostatecznie spowodował, że ok. 2500 osób ze społeczności Sinti zostało przetransportowanych z Niemiec do robót przymusowych na terenie Polski. Podobny los spotkał ludność cygańską żyjącą w Czechach i Austrii. Osoby te znalazły się ostatecznie w obozach i gettach. Znaczna część ludności Sinti uważała się za równoprawnych obywateli Niemiec, odczuwając przy tym silną identyfikację obywatelską. Przedwojenna populacja ludności Sinti liczyła ok. 20 tys. osób. W wyniku działań eksterminacyjnych wymordowano ok. 15 tys. osób, czyli aż 85\% ludności Sinti. Zdaniem Sławomira Kapralskiego działania prowadzone przez NSDAP nie były skoordynowane i zaplanowane. Oznacza to, że ludobójstwo może się zdarzyć w każdych okolicznościach, miejscu i czasie. Zgromadzenie Ogólne ONZ ustanowiło dzień 2 sierpnia Międzynarodowym Dniem Pamięci o zagładzie Romów i Sinti (Kapralski 2011, 2012).

\section{Cyganie w PRL}

W grudniu 1949 r. przeprowadzono ogólnokrajowy spis ludności cygańskiej, z którego wynikało, że 25\% ludności cygańskiej to ludność osiadła mieszkająca na południu Polski. Proces zbierania danych statystycznych był pierwszym, wstępnym etapem do rozwiązania tzw. problemu cygańskiego w Polskiej Rzeczpospolitej Ludowej.

W 1952 r. Prezydium Rządu wydało uchwałę nr 452/52 w sprawie pomocy ludności cygańskiej przy przechodzeniu na osiadły tryb życia. W uchwale tej czytamy: „Prezydia rad narodowych wszystkich szczebli rozwiną na terenach, gdzie przebywają Cyganie, szeroką akcję wychowawczego oddziaływania na ludność cygańską w kierunku porzucenia przez nich koczowniczego trybu życia i przejścia na tory produktywnego życia osiadłego" (Prez. Rząd. 452/52 z 1952). Na terenie wszystkich województw zarejestrowano w tamtym czasie 140 taborów, spisano 8878 osób (4802 osiadłych i 4076 koczujących), sfotografowano 1100 osób, a daktyloskopowano 1862. Wydano 3804 akty stanu cywilnego, 1106 kart meldunkowych i 137 ksiąg meldunkowych. Zasadniczym celem akcji miała być ankietyzacja i paszportyzacja Romów polegająca na ustaleniu danych personalnych i miejsca zamieszkania oraz wręczeniu zaświadczeń rejestracyjnych, zastępujących dowody tożsamości. Obowiązkową paszportyzacją zostały objęte 6174 osoby. Spośród nich 3251 osób było nieletnich (do 16 roku życia), a 2923 osoby były dorosłe (Mirga 1997: 167-168). Uchwała wprowadzała rozbudowany system zachęt zamiast politycznych represji, które miałyby zmusić Cyganów do asymilacji i podjęcia przez nich pracy. Strategią przetrwania okazała się mimikra stosowana przez Cyganów. Polegała ono na naśladowaniu wybranych wzorów kultury większościowej. Jak podkreślają Elena Marushiakova i Vesselin Popov, społeczności romskie posiadają więcej cech podobnych z większościowym otoczeniem społecznym, w którym żyją, niż łączących ich z pozostałymi grupami romskimi. Środowisko społeczne przyczynia się do 
wykształcenia społecznych predyspozycji, pozwalając na przetrwanie grupy etnicznej (Marushiakova, Popov 2011; Caban 2008; Ficowski 1965).

Późniejsza „akcja zatrzymania taborów” została zainicjowana 23 marca 1964 r. Próby osiedlenia wędrownych Romów były kontynuowane w następnych dekadach. Wielu autorów uważa, że przyczynkiem formalnym do „zatrzymania taborów” i akcji osiedleńczej Romów było pismo Prezesa Rady Ministrów Józefa Cyrankiewicza wydane 11 marca 1964 r. Wprowadzono w tamtym czasie wiele ustaw, które utrudniały przemieszczanie się wozami po kraju. Były to następujące ustawy: o zgromadzeniach (utrudniała nielegalne przebywanie większej liczby osób w jednym miejscu); o zwalczaniu chorób zakaźnych (zaniedbanie obowiązku szczepień ochronnych); o ochronie przeciwpożarowej (palenie ognisk w lesie, brak sprzętu gaśniczego), o obowiązku szkolnym (nieposyłanie dzieci do szkół). Polityka państwa nie była zdecydowana, prowadzono ją w sposób mało konsekwentny i ostatecznie nie była skuteczna. Z. Barany określa ją jako politykę „chaotycznych interwencji” (Barany 2002).

W połowie XIX i na początku XX w. pojawiły się duże wozy mieszkalne dwojakiego rodzaju. Pierwsze, nieco starsze, posiadały tzw. budy i jeździli nimi przedstawiciele grupy Polska Roma oraz pozostałe szczepy cygańskie. Z kolei nieco młodsze barakowozy były ciągnięte przez jednego lub dwa konie i stanowiły własność zamożniejszych grup cygańskich, zwłaszcza Lowarów lub Kelderaszy (Mróz 1979).

\section{Wymiar współczesny}

Wędrowne grupy romskie funkcjonowały na terytorium komunistycznych bloków wschodnich. Najbardziej widoczne były w Polsce, gdzie stanowiły 75\% ogółu ludności romskiej; w ZSRR - 75\%, w Rumunii i Jugosławii - 35\%; w Bułgarii i Czechosłowacji - 5\%; na Węgrzech i w Albanii - 25\%.

E. Marushiakova i V. Popov przedstawiają trzy ogólne modele polityczne stosunku państw wobec zjawiska osiedlenia się Cyganów. Pierwszym opisywanym państwem jest Imperium Osmańskie, w którym cywilny status Cyganów został zachowany. Był on jednak niższy od statusu ludności niecygańskiej. Ostatecznie jednak celem tego modelu była otwarta możliwość dobrowolnej asymilacji. Drugi model był realizowany w monarchii Austro-Węgier (do której terytorium należała również południowa część Polski). Model ten zakładał silną integrację, a co za tym idzie, również asymilację społeczności cygańskich. Trzeci model był realizowany w Imperium Rosyjskim i zakładał brak integracji Cyganów ze społeczno-kulturowymi wzorcami. To oznaczało, że polityka integracyjna w praktyce nie istniała. Modele te pokazują, w jak różnorodny sposób realizowana była polityka wobec Cyganów w wybranych krajach.

Dekret związany z przymusowym osiedleniem się Cyganów realizowany w ZSRR (1958-1959) został zastosowany także na Węgrzech, w Czechosłowacji, w Bułgarii i Polsce. Proces ten przedłużył się do 1964 r. W Rumunii, byłej Jugosławii i Albanii przymus osiedlenia się zaczął obowiązywać w latach 60. i 70. XX w.

W przeciwieństwie do Cyganów w państwach postkomunistycznych, Travellers mieszkający na Wyspach Brytyjskich nadal pozostają ludnością nomadyczną (szkoccy, walijscy i angielscy Travellers). Zamieszkują tam grupy cygańskie Wędrowców (Travellers) i Druciarzy (Tinkers). Ich osiadłość została wymuszona stosunkowo niedawno. Mieszkają w przyczepach kempingowych lub domkach letniskowych przy terenach zielonych. Ich oficjalnym językiem jest angielski. W Irlandii trudnili się handlem końmi, handlem obwoźnym, czyszczeniem kominów, drobnymi naprawami, muzykowaniem itd. (Radzewicz 2018). Travellers zostali uznani za najstarszą z grup węd rownych w Europie zachodniej.

Wyniki badań genetycznych zanegowały istnienie powiązania pomiędzy Romami a irlandzkimi Travellersami. Nie można zatem ich uznać w kontekście genetycznym za Romów. Prowadzą jednak nomadyczny tryb życia, który zalicza ich do tzw. nomadów perypatetycznych (ang. peripatetic). Wędrówki tej populacji ograniczały się w przeszłości do Wysp Brytyjskich, lecz obecnie są oni również rozpoznawani w innych miejscach Europy (np. w Szwecji jako heathers i tatars (szw. tattare). Jak pisze Radzewicz, nie kupują już oni wozów od Cyganów angielskich, a starsze profesje prawie bezpowrotnie wyginęły.

Najciekawszą ornamentykę miały wozy angielskie i polskie (zwłaszcza Kelderaszy lub Lowarów). Jeśli chodzi o wozy jeżdżące po drogach Wielkiej Brytanii, to były bardzo różnorodne. Mróz podaje typologię owych wozów z uwagi na ich kształt: Ledge, Reading, Bow-top, Burton, Pot-cart i Open-lot (Mróz 1979: 90). 
We Francji Romowie, ze względu na równościową politykę państwa, są eufemistycznie określani jako tzw. ludzie wędrowni (Gens du voyage). To oznacza, że ludność ta ma możliwość swobodnego przemieszczania się w świetle prawa EU oraz regulacji administracyjnych m.in. z 1960 i 2000 r. W praktycznym wymiarze grupom tym umożliwiono swobodne przemieszczanie się np. pomiędzy Francją a Rumunią oraz Bułgarią. Szacuje się, że społeczność Gens du voyage jest 400-tysięczną populacją, z czego 15-20 tys. osób to migranci, a ich znaczny odsetek, bo aż 90\% prawdopodobnie pochodzi z Rumunii (Orbin-Oliver 2016: 250-251).

W artykule E. Marushiakova i V. Popov opisali zjawisko nomadyzmu z perspektywy romskie jako równoprawny głos na temat ich społecznej emancypacji: „Letter to Stalin: Roma Activism vs. Gypsy Nomadism in Central, South-Eastern and Eastern Europe before WWII”. Autorzy podkreślają, że Romowie są postrzegani jako bierne podmioty polityki władz, a nie jako aktywni twórcy własnej historii (zob. też Mirga i Mróz 1994: 32). Jednocześnie sugerują, że w ten sposób brakuje poglądów i reakcji Romów i ich wizji przyszłości. Romowie są częścią otoczenia społecznego, dlatego ich głos w tej sprawie jest znaczący. Cyganie postrzegani są do dzisiaj jako „wieczni” koczownicy. Pojęcie nomadyzmu jest - o czym piszą autorzy - używane w dwojakim kontekście. Służy legitymizacji działań prowadzących do ich dyskryminacji we współczesnej Europie. Dodatkowo istnieją, ich zdaniem, dwa dyskursy w odniesieniu do ludności romskiej. Na płaszczyźnie historycznej Romowie byli i nadal są rozpoznawani 1) jako problem oraz 2) jako ofiary. Oba przeciwne dyskursy łączy nieobecność i brak partycypacji Romów w ich własnej narracji społecznej. To sprawia, że są oni zależni od społeczeństw większościowych. Pomimo że około 96\% Cyganów na świecie prowadzi życie osiadłe, to wielu z nich uważa nomadyzm za swój sposób interpretowania własnej tożsamości w kontekstach symbolicznych i mentalnych (jako pozytywny autostereotyp). W taki sposób rozumie własną kulturę grupa Cyganów Karpackich (tzw. Bergitka Roma) żyjących w większości na południu Polski (Lubecka 2005).

\section{Zakończenie}

Dzieje Romów (przedstawione tutaj w sposób pobieżny) to pasmo niekończących się państwowych i politycznych represji oraz upokorzeń, których doznawali na terytorium Europy Wschodniej i Środkowej. Te krzywdy i upokorzenia dają Cyganom możliwość szukania ich genezy w obszarze kilku mechanizmów naukowej refleksji/teorii. Pierwszy to mechanizm „ofiar zastępczych”, zgodnie z którym Cyganie jako ludność aspołeczna mieli być figurami retorycznymi. Rządy wielu krajów stosowały ten model, aby postraszyć przed zgubnymi skutkami tych, którzy nie chcieli się podporządkować normom społecznym. Drugi z nich, skądinąd dobrze znany, to mechanizm tzw. kozła ofiarnego, opisany przez R. Girarda. Praca tego autora dotyczy przede wszystkim ludności żydowskiej, lecz uważam, że ludność cygańska może również uchodzić za ludność narażoną na prześladowania w kontekstach historycznych. Funkcjonowanie Cyganów na dole drabiny społecznej i ich ułomność w wielu obszarach ludzkiej egzystencji jako antyteza postaw ogólnoludzkich to stereotyp prześladowczy zbudowany na płaszczyźnie istniejących różnic: „Wyraża nienawiść nie do różnicy, lecz do jej braku. To nie inne nomos widzi się w innym, lecz anomalię, nie inną normę, lecz anormalność" (Girard 1987: 26). Cyganie gdy rozpoczęli wędrówki (w połowie XVI w.), byli również postrzegani jako ludzie gościńca - symbol „ludzi złych” i aspołecznych. Znakiem ich inności była wędrówka (nomadyzm lub półnomadyzm). Istotnym elementem w koncepcji Gerarda jest zaakcentowanie istnienia mitologii (także tej odwołującej się do C. Lévi-Straussa) jako monstrualności moralnej i fizycznej, które idą ze sobą w parze, „usprawiedliwiając prześladowanie ułomnego” (tu: Cyganów). Znakomitym przykładem tego zjawiska była fala emigracji Kełderaszy i Lowarów, która w drugiej połowie XIX w. zalała wiele krajów ówczesnej Europy.

Doba romantyzmu w sposób istotny przyczyniła się do utrwalenia wizerunku Cygana jako „wolnego ptaka”, „człowieka wolnego” i „wiecznego tułacza” w Europie. Przedstawiano Cyganów z perspektywy mitycznej (stereotyp negatywny lub pozytywny). Jak dodaje P. Sztompka, jest to w zasadzie perspektywa myślenia potocznego na temat zjawisk społecznych. Jest ona jednocześnie „jednostronna” i „uproszczona”, a dodatkowo „fragmentaryczna” i „niespójna”. Opiera się np. na pozornym fakcie czy micie, stojąc w opozycji do wiedzy socjologicznej, która powinna: „zaglądać pod powierzchnię zjawisk naocznie postrzegalnych, szukając głębszych, ukrytych warstw rzeczywistości społecznej" (Sztompka 2002: 21). Wiele polityk realizowanych w tamtym czasie (od XV-XVIII w.) okazało się mało skutecznych. Cyganów początkowo przechowywano 
dobrach prywatnych (np. Sanguszków, Radziwiłłów i Potockich) (Mróz 2001: 256-272). Rząd rozprawiał się z Cyganami na terenie Rzeczypospolitej. Metody te zbiegały się ze zmianami w obrębie przyjętych prądów myślowych modernizującej się Europy. Ale ich skuteczność pozostawiała wiele do życzenia. Cyganie znajdowali schronienie wśród pozostałych nie-Cyganów.

Można powiedzieć, że Cyganie nie byli ludnością, która mogła wpisać się w główne nurty myślowe w zmieniających się krajach ówczesnej centralnej i południowej Europy. Pozostali ludnością zmarginalizowaną i coraz bardziej dyskryminowaną (pozostając do dzisiaj na obrzeżach środowisk społecznych). W XIX w. coraz bardziej popularne stawały się teorie rasowe. Poszczególne grupy ludzkie postrzegano w kategoriach trwałych różnic kategorii biologicznych. Doktor Ritter uważał, że Cyganie to: „ludność prymitywna, wykazująca niezdolność w rzeczywistym procesie adaptacji społecznej”, dlatego należy ją traktować jako „element bardzo zagrażający czystości rasy niemieckiej” (Novitch 1984: 24). Dzisiaj wiemy, że spora niechęć wobec Cyganów jest powodowana innymi motywami. Zdaniem E. Nowickiej: „Problem swojskości i obcości rozgrywa się na granicy między postrzeżeniową a wartościującą płaszczyzną inności - na przejściu od tego, co inne w sensie deskryptywnym, do tego, co inne w sensie psychologicznym czy społecznym, a więc od opisu do oceny, od faktu do wartości” (Nowicka 1995: 361). Nie ulega jednak wątpliwości, że Cyganie, od wielu dekad, są (pod wieloma względami) jedną z najbardziej nielubianych grup społecznych w Polsce.

Warto przytoczyć w tym miejscu jeszcze jedną opinię, która wiele mówi na temat strategii adaptacji Cyganów do warunków większościowych, a dokładniej strategii mimikry stosowanej przez tę grupę etniczną; L. Mróz pisze: „W trakcie wędrówek po Europie przejęli oni tak wiele cech obcych swej dawnej kulturze, że ogromnie trudno jest dziś wydobyć spod zapożyczeń te najbardziej własne, autentyczne elementy" (Mróz 2001: 80). Dzisiaj niewiele można powiedzieć na temat tego, które cechy są dla Cyganów znaczące, a nie. Wiele cech wraz z upływem czasu zatarło swoje pierwotne znaczenia, a ich rekonstrukcja jest już niemożliwa. Proces mimikry warunkował przetrwanie grupowe i odwoływał się do ich egzystencji. Zdaniem E. Nowickiej: „w przypadku kontaktu Romów z rozmaitymi wersjami narodowymi kultury europejskiej proces akulturacji dokonywał się na drodze kompartmentalizacji” (Nowicka 2011: 250). Jest to idea, która pozwala uchwycić zakres wielowiekowej wędrówki jako efekt represji wobec Romów, mającej dalekie przyczyny historyczne na terenie niemalże całej Europy, w tym także w Królestwie Rzeczypospolitej i Księstwie Litewskim.

\section{Bibliografia}

Acton T. (1974), Gypsy Politics and Social Change; The Development of Ethnic Ideology and Pressure Politics among British

Gypsies from Victorian Reformism to Romany N ationalism. London: Routledge and K. Paul.

Acton T. (1981), Gypsies. London: Macdonald Phoebus.

Apanowicz J. (2002), Metodologia ogólna. Gdynia: Wydawnictwo Diecezji Pelplińskiej „Bernardinum”.

Baranowski B. (1986), Ludzie gościńca XVII-XVIII w. Łódź: Wydawnictwo Łódzkie.

Barany Z. (2002), The East European Gypsies. Regime Change, Marginality, and Ethnopolitics. Cambridge: Cambridge University Press.

Bartosz A. (2009), Gdziez te wozy kolorowe? „Studia Romologica”, t. 2. Tarnów: Muzeum Okręgowe w Tarnowie, s. 267-283.

Chałupczak H. Browarek T. (1998), Mniejszości narodowe w Polsce 1918-1995. Lublin: Wydawnictwo Uniwersytetu Marii Curie-Skłodowskiej.

Crowe D.M. (1995), A History of the Gypsies of Eastern Europe and Russia, New York: St. Martin's Press.

Ficowski J. (1965), Cyganie na polskich drogach. Kraków: Wydawnictwo Literackie.

Frazer A. (2001), Dzieje Cyganów, tłum. E. Klekot. Warszawa: Państwowy Instytut Wydawniczy.

Geremek B. (1984), Cyganie w Europie średniowiecznej i nowożytnej. „Przegląd Historyczny” 75/3, s. 569-596.

Girard R. (1987), Koziot ofiarny, Łódź: Wydawnictwo Łódzkie.

Hancock I. (2002), We are the Romani People. Ames am e Rromane džene. Hatfield: University of Hertfordshire Press. Hayden R. (1979), The Cultural Ecology of Service Nomads. „The Eastern Anthropologist” 32, 4, s. 297-309.

Hubschmannova M. (1972), What Can Sociology Suggest About the Origin of Roma? „Archiv Orientální” 40, s. 51-64. Kamiński I.M. (1980), The state of Ambiguity. Studies of Gypsy refugees. Gothenburg: University of Gothenburg. 
Kapralski S. (2012), Naród z popiołów. Pamięć zagtady a tożsamość Romów. Warszawa: Wydawnictwo Naukowe Scholar. Kapralski S. (2018), Mit Taboru. Kwartalnik „Dialog-Pheniben” 27, s. 10-20.

Kendrick D., Puxon G. (1972), The Destiny of Europe's Gypsies. London: Chatto - Heineman for Sussex.

Kradin N. (2002), Nomadism, Evolution, and World-Systems: Pastoral Societies in Theories of Historical Development. "Journal of World-Systems Research”, November.

Lévi-Strauss C. (1978), Myth and Meaning. Toronto: University of Toronto Press.

Liégeois J.P. (1995), Roma, Gypsies and Travellers. Socio-cultural data. Strasbourg: Council of Europe Press.

Lubecka A. (2005), Tożsamość kulturowa Bergitka Roma. Kraków: Wydawnictwo Księgarnia Akademicka.

Marushiakova E., Popov V. (2018), Roma labelling: policy and academia. „Slovenský národopis”, vol. 66 , no. 4, s. $385-418$.

Marushiakova E., Popov V. (2020), Letter to Stalin': Roma Activism vs. Gypsy Nomadism in Central, South-Eastern and Eastern Europe before WWII. „Social Inclusion”, Vol. 8, Issue 2, s. 265-276.

Mirga A. (1997), Romowie w historii najnowszej Polski [w:] Mniejszości narodowe w Polsce, red. Z. Kurcz. Wrocław: Wydawnictwo Uniwersytetu Wrocławskiego.

Mirga A., Mróz L. (1994), Cyganie. Odmienność i nietolerancja. Warszawa: Wydawnictwo PWN.

Mróz L. (1979), Wozy cygańskie. „Polska Sztuka Ludowa”, nr 2. s. 77-94.

Mróz L. (1995), O Filistynach, Cyganach alias Watęsach. Z dziejów poznawania Romów w Polsce. „Lud”, t. 78, s. 341-356.

Mróz L. (2001), Dzieje Cyganów - Romów w Rzeczypospolitej XV-XVIII w. Warszawa: Wydawnictwo DiG.

Mróz L. (2010), Cyganie - Romowie [w:] Pod wspólnym niebem. Narody dawnej Rzeczypospolitej, red. M. Kopczyński, W. Tygielski. Warszawa: Wydawnictwo Bellona, s. 161-179.

Nemeth D.J. (1970), Nomad Gypsies in Los Angeles: Patterns of Livelihood. San Fernando State College (nieopublikowana praca magisterska).

Novitch M. (1984), Half a million Gypsies victims of the Nazi terror. „The Unesco Courier” (The Gypsies).

Nowicka E. (2011), Romowie i kontrola spoteczna. Co zrobić z Romami? [w:] Prawo i tad spoteczny. Integralnokulturowa analiza zagadnienia racjonalności. Artykuty i szkice, red. J. UtratMilecki, Warszawa: Wydawnictwa Uniwersytetu Warszawskiego.

Nowicka E., Cieślińska B. (2005), Wędrowcy i migranci. Kraków: Zakład Wydawniczy „Nomos”.

Orbin-Olivier S. (2016), The Roma Population: A Borderline Case [w:] Constructing the Person in EU Law, red. L. Azoulai, S. Barbou des Places, E. Pataut. Oregon: Hart Publishing, Oxford and Portland.

Radzewicz E. (2018), O idei ochrony niematerialnego dziedzictwa kulturowego irlandzkich Travellerów, „Studia Romologica” nr 12. Tarnów: Muzeum Okręgowe w Tarnowie, s. 177-198.

Sztompka P. (2002), Socjologia. Analiza spoteczeństwa. Karków: Wydawnictwo ZNAK.

Varady R.G. (1982), Imperial Teamsters to Motorized Cattle Dealers: Observations on the History of Banjaras or Indian Gypsies, Fourth Series 2; 1, JGLS.

William W.A. (1982), A Brief Talk About Tin. Washington: The Pan American Union,

\section{Źródła internetowe}

Caban A.M. (2008), Osiedlanie Cyganów/Romów po 1952 roku na Lubelszczyźnie. Lublin: Uniwersytet Marii CurieSkłodowskiej (nieopublikowana praca magisterska), https://docplayer.pl/9299334-Osiedlanie-cyganow-romow-po1952-roku-na- lubelszczyznie.html (dostęp: 30.05.2021).

FRA - European Union Agency for Fundamental Rights (22 June 2016), Measuring Roma inclusion strategies a fundamental rights based approach to indicators, https:/unece.org/fileadmin/DAM/stats/documents/ece/ces/ ge.15/2016/Sem/WP20_FR A_ENG.pdf (dostęp: 30.05.2021).

GUS - Główny Urząd Statystyczny, Wyniki Narodowego Spisu Powszechnego Ludności i Mieszkań (2011), https:// stat.gov.pl/spisy-powszechne/nsp-2011/nsp-2011-wyniki (dostęp: 30.05.2021).

MSWIA-Program-integracji-spolecznosci-romskiej-w-Polsce-na-lata-2014-2020. http://mniejszosci.narodowe.mswia. gov.pl/mne/romowie/program-na-rzecz-spole/program-na-hrzecz-spole/tresc-programu-na-rzec/6670, TrescProgramu.html (dostęp: 30.05.2021). 